\title{
GOLDEN PROPORTION GIGI INICISIVUS SENTRAL RAHANG ATAS SUKU BALI DI FAKULTAS KEDOKTERAN GIGI UNIVERSITAS MAHASARASWATI DENPASAR
}

\author{
Norman Hidajah, Ketut Virtika Ayu, Dwis Syahrul \\ Bagian Ortodonti, Fakultas Kedokteran gigi, Universitas Mahasaraswati Denpasar \\ Email: drgnorman@yahoo.com
}

\begin{abstract}
Tooth size determines a person's aesthetics. Some guidelines that can help in determining the size of the maxillary anterior teeth are pre-extraction instructions such as facial photographs, diagnostic models, radiographic photographs, and extracted teeth. If the instructions before extraction are not obtained then an ideal proportionis needed. This study aims to determine whether or not thereis a relationship between the width and high of the face to the mesiodistal and cervico incisal of the maxillary central incisors and what is the proportion of these teeth. The research method used is analytic observasional research with design of crosssectional, using samples of 47 subjects from Bali's Trobe age 17-25 at Faculty of Dentistry in Mahasaraswati University Denpasar. The result to research show a significant correlation between face width and high to the size of mesiodistal and servico incisal of the maxillary centralincisorson Bali'sTrobe. The proportion of face and teeth of Balinese belonging to the Mongoloid race was obtain $1: 1,639$ and mesiodistal and cervicoincisal of the maxillary central incisors where $1: 1,6409$
\end{abstract}

Keywords : goldenproportion, maxillarycentralincisors, Balinese

\section{PENDAHULUAN}

Perkembangan dalam dunia teknologi dan informasi belakangan ini membuat pesatnya perkembangan ilmu kedokteran gigi. Perkembangan tersebut dapat berupa perkembangan teknik rehabilitasi estetik di bidang kedokteran gigi membawa sebuah perubahan paradigma di bidang restorasi dan estetik. Cantik adalah sesuatu yang memberikan derajat tertinggi dari kesenangan pada perasaan atau pikiran dan menyarankan bahwa objek tersebut kurang lebih mendekati dari konsep ideal. Kecantikan dalam Kedokteran Gigi tergantung pada komponen diantaranya seperti posisi, ukuran, dan warna gigi yang sangat berperan pada daya pikat atau estetik wajah. ${ }^{1}$

Secara umum bentuk wajah (facial) dipengaruhi oleh bentuk kepala, jenis kelamin dan usia. Bentuk wajah setiap orang berbeda karena ada kombinasi unik dari kontur nasal, bibir, rahang atas dan rahang bawah yang memudahkan seseorang untuk mengenal satu sama lain. Bagian - bagian yang dianggap mempengaruhi wajah adalah tulang pipi, hidung, rahang atas, rahang bawah, mulut, dagu, mata, dahi dan supra orbital. ${ }^{2}$

Salah satu tujuan dari perawatan ortodontik adalah estetika. Konsep estetika sebagai ilmu sangat terkait dengan konsep kecantikan dan mengandung komponen yang sangat subyektif. Meski berbeda, estetika dan keindahan saling melengkapi. Dalam kedokteran gigi, estetika bertujuan untuk menciptakan keindahan dan daya tarik guna meningkatkan harga diri, dan membuatnya merasa puas terhadap bagian penting dari tubuh mereka, sehingga merasa ekspresif serta dihargai secara sosial. $^{3}$ Hal yang harus dipertimbangkan dalam perawatan ortodontik salah satunya adalah lebar mesiodistal gigi. Lebar mesiodistal gig iberkaitan dengan garis lengkung rahang yang dapat menjadi faktor predisposisi terjadinya gigi berjejal dan maloklusi gigi. ${ }^{4}$

Hubungan gigi geligi saat oklusi normal akan mempengaruhi posisi overjet dan overbite yang normal kemudian akan membentuk kesesuaian lengkung gigi dan inklinasi gigi antara rahang atas dan rahangbawah. Ketidak sesuaian ukuran mesiodistal gigi terhadap lengkung rahang merupakan salah satu penyebab terjadinya maloklusi. Dilihat dari ukuran mesiodistal gigi, jika mesiodistal gigi lebih besar atau lebih kecil dari normal maka akan menyebabkan perubahan bentuk lengkung gigi dan inklinasi gigi. ${ }^{5}$

Ukuran mesiodistal dan servikoinsisal gigi setiap individu adalah berbeda, setiap populasi juga berbeda dengan populasi lainnya. Data ukuran mesiodistal dan servikoinsisal gigi penting sebagai informasi sebelum suatu perawatan di kedokteran gigi dimulai terutama di bidang Konservasi, Ortodonsia, Forensik dan Prostodonsia. Adanya variasi ukuran mesiodistal dan serviko insisal gigi disebabkan karena pengaruh faktor ras, genetik, lingkungan, suku, jenis kelamin dan faktor penyakit.

Suku Bali adalah suku yang menetap dan berasal dari Pulau Bali. Suku Bali bukan termasuk ras Kaukasoid maupun Negroid, melainkan sub ras Malayan Mongoloid. Ciri khas utama anggota ras ini ialah rambut berwarna hitam yang lurus,bercak 
mongol pada saat lahir dan lipatan pada mata yang seringkali disebut mata sipit. Selain itu anggota ras manusia ini sering kali lebih kecil dan pendek daripada ras Kaukasoid. ${ }^{6}$ Menurut penelitian Putra dkk (2017) rata-rata wajah laki-laki pada suku Bali berbentuk ellips, sedangkan pada perempuan berbentuk bulat.

Berdasarkan hal tersebut diatas penelitian ini bertujuan untuk mengetahui hubungan lebar dan tinggi wajah dengan ukuran mesiodistal dan serviko insisal gigi insisivus sentral rahang atas beserta prosposi gigi anterior mahasiswa Suku Bali Fakultas Kedokteran Gigi Universitas Mahasaraswati Denpasar.

\section{BAHAN DAN METODE}

Alat dan bahan

Alat dan bahan yang digunakan dalam penelitian ini antara lain : kapas dan alkohol $70 \%$, sliding kaliper, kaca mulut, masker, handscone, nearbecken, alat tulis dan kursi.

\section{Rancangan Penelititan}

Rancangan penelitian yang digunakan pada penelitian ini adalah analitik observasional dan pendekatan cross sectional. ${ }^{7}$ Sampel yang digunakan adalah mahasiswa suku Bali FKG Universitas Mahasaraswati Denpasar dalam kurun waktu penelitian yang memenuhi kriteria inklusi yaitu suku Bali, berusia 17 tahun sampai dengan 25 tahun, tidak pernah dan tidak sedang melakukan perawatan ortodonti, gigi permanen lengkap sampai molar dua, prosporsi wajah normal dan tidak pernah menjalani tindakan bedah yang mengubah wajah, gigi insisivus pertama rahang atas normal dan tidak pernah dirawat dengan tindakan konservasi dan bersedia ikut dalam penelitian. Kriteria eksklusi adalah apabila sampel tidak hadir saat pengambilan data. Jumlah sampel diperoleh dengan menggunakan rumus Slovin, $\mathrm{n}=$ $\mathrm{N} /\left(1+\left(\mathrm{N}_{\mathrm{x}} \mathrm{e}^{2}\right)\right)$, sampel berjumlah 47 orang. Sampel yang digunakan pada penelitian ini diambil dengan teknik simple random sampling, yaitu pemilihan sampel dilakukan secara acak dari populasi yang sudah ditentukan oleh peneliti dan didasarkan dalam suatu kriteria inklusi dan eksklusi yang dibuat oleh peneliti. ${ }^{8}$

Protokol Penelitian

Sampel dipilih berdasarkan kriteria inklusi dan eksklusi. Sampel yang sesuai diberikan lembar informed consent, subjek diukur untuk mendapatkan lebar dan panjang wajah serta ukuran mesiodistal dan serviko insisal gigi insisivus sentral rahang atas, mengukur lebar dan panjang wajah menggunakan sliding caliper, mengukur lebar wajah mulai dari soft tissue of zygomaticum paling kiri lalu diukur sampai ke soft tissue of zygomaticum paling kanan, mengukur panjang wajah mulai dari soft tissue of nation (N) hingga bagian soft tissue of menton (Me) menggunakan sliding caliper. ${ }^{9}$ Selanjutnya mengukur mesiodistal gigi insisivus sentral rahang atas menggunakan sliding caliper mulai dari sisi paling pinggir kanan gigi yang berkontak dengan gigi tetangganya hingga sisi paling pinggir kiri gigi yang berkontak dengan gigi tetangganya. Pengukuran serviko insisal gigi insisivus sentral rahang atas menggunakan sliding caliper mulai dari garis servikal hingga ke puncak insisisal gigi. Pengukuran dilakukan masing-masing sebanyak tiga kali untuk mendapatkan hasil yang lebih akurat. Kemudian catat semua pengukuran dalam form yang sudah disediakan. Perhitungan golden proportion (GP) diperoleh dengan menggunakan rumus :

$$
G P=\frac{\text { ukuran terkecil }}{\text { ukuran terbesar }}=\frac{\text { ukuran terbesar }}{\text { ukuran terkecil }+ \text { ukuran terbesar }}
$$

Analisis hubungan lebar dan panjang wajah dengan ukuran mesiodistal dan servikoinsisal gigi insisvus sentral rahang atas menggunakan uji parametrik korelasi Pearson. ${ }^{8}$

\section{HASIL DAN PEMBAHASAN}

Hasil pengukuran dimasukan dalam tabel.

Tabel 1. Deksripsi Data Masing-masing Variabel Penelitian

\begin{tabular}{|c|c|c|c|c|c|}
\hline & $\mathrm{N}$ & Min. & Max. & Mean & SD \\
\hline Lebar Wajah & 47 & 112.30 & 144.60 & 126.59 & 6.63 \\
\hline Panjang Wajah & 47 & 95.70 & 134.10 & 110.71 & 7.76 \\
\hline $\begin{array}{l}\text { Ukuran Gigi } 11 \\
\text { mesio-distal }\end{array}$ & 47 & 6.80 & 10.00 & 8.34 & .65 \\
\hline $\begin{array}{l}\text { Ukuran Gigi } 11 \\
\text { serviko-insisal }\end{array}$ & 47 & 7.40 & 11.40 & 9.53 & $\begin{array}{c}12.0 \\
6\end{array}$ \\
\hline $\begin{array}{l}\text { Ukuran Gigi } 21 \\
\text { mesio-distal }\end{array}$ & 47 & 6.80 & 10.20 & 8.44 & .61 \\
\hline $\begin{array}{l}\text { Ukuran gigi } 21 \\
\text { serviko - incisal }\end{array}$ & 47 & 7.80 & 10.80 & 9.56 & .71 \\
\hline
\end{tabular}

Hasil pengujian parametrik korelasi Pearson, hubungan lebar wajah terhadap mesiodistal gigi 11 diperoleh nilai korelasi sebesar 0,331 dengan taraf signifikansi $0,023<0,05$. Artinya terdapat hubungan antara lebar wajah terhadap ukuran mesiodistal rahang atas mahasiswa suku Bali Fakultas Kedokteran Gigi Universitas Mahasaraswati Denpasar.

Hasil pengujian hubungan lebar wajah terhadap mesiodistal gigi 21 diperoleh nilai korelasi sebesar 0,375 dengan taraf signifikansi $0,009<0,05$. Artinya terdapat hubungan antara lebar wajah terhadap ukuran mesiodistal rahang atas mahasiswa suku Bali Fakultas Kedokteran Gigi Universitas Mahasaraswati Denpasar.

Hasil pengujian hubungan panjang wajah terhadap servikoinsisal gigi 11 diperoleh nilai korelasi sebesar 0,414 dengan taraf signifikansi 
$0,004<0,05$. Artinya terdapat hubungan antara panjang wajah terhadap ukuran servikoinsisal gigi 11 rahang atas mahasiswa suku Bali Fakultas Kedokteran Gigi Universitas Mahasaraswati Denpasar.

Hasil pengujian hubungan panjang wajah terhadap servikoinsisal gigi 21 diperoleh nilai korelasi sebesar 0,439 dengan taraf signifikansi $0,002<0,05$. Artinya terdapat hubungan antara panjang wajah terhadap ukuran servikoinsisal gigi 21 rahang atas mahasiswa suku Bali Fakultas Kedokteran Gigi Universitas Mahasaraswati Denpasar.

Dalam penelitian ini dapat dibuat sebuah proporsi sebagai mana konsep dari Golden Proportion yang dideskripsikan sebagai berikut "Proporsi terkecil ke terbesar sama dengan proporsi terbesar kesemuanya" (Bali 2013). Beberapa bagian tubuh yang jika dibandingkan akan sesuai proporsinya dengan Golden Proportion yakni lebar wajah dengan panjang wajah, ukuran gigi insisivus sentral rahang atas Golden proportion dengan insisivus lateralis rahang atas dan lain sebagainya. Ukuran Golden Proportion yaitu lebar wajah (diukur dari byzigomatic sampai byzigomatic) 1,618 kali lebih lebar daripada panjang wajah (diukur dari nation sampai ke menton), serta ukuran serviko insisal gigi insisivus sentral rahang atas lebih panjang 1,618 kali daripada ukuran mesiodistal gigi insisivus sentral rahang atas. Pada penilaian terdahulu didapatkan berdasarkan pengukuran pada ras Kaukasoid (Jefferson 2004). ${ }^{10}$ Pada penelitian ini didapat sebuah proporsi sendiri (Golden Proportion) terkhusus ras Mongoloid pada suku Bali. Golden proportion pada suku Bali yang termasuk ras Mongoloid yakni lebar dan Panjang wajah didapat sebesar 1 : 1,639 serta pada mesiodistal dan serviko insisal gigi insisivus sentral rahang atas yaitu sebesar $1: 1,6409$.

Proporsi vertikal wajah dengan metode Facial Thirds menyatakan bahwa wajah yang proporsional dapat dibagi menjadi sepertiga yang sama dengan menggambar garis horizontal melalui garis rambut pada dahi, alis, pangkal hidung, dan tepi dagu. Jarak antara bibir dan dagu harus dua kali lipat jarak antara pangkal hidung dan bibir. ${ }^{8}$ Proporsi vertikal wajah dibagi menjadi tiga bagian, yaitu sepertiga atas (trichion-glabella), sepertiga tengah (glabella-subnasal) dan sepertiga bawah (subnasal-menton). Secara umum tinggi wajah tengah disebut juga sebagai tinggi wajah atas. ${ }^{9}$

Salah satu prinsip estetis dalam menentukan ukuran gigi-geligi anterior adalah lebar gigi. Beberapa pedoman yang dapat membantu dokter gigi dalam menentukan lebar gigi-geligi anterior rahang atas adalah petunjuk sebelum pencabutan meliputi foto wajah, model diagnostik, foto radiografi, gigi keluarga terdekat, serta gigi yang sudah dicabut. Apabila petunjuk sebelum pencabutan tidak diperoleh, maka dokter gigi dapat menggunakan pedoman pengukuran wajah seperti lebar bizigomatik, lebar sudut mulut, jarak antar pupil, lebar hidung, permukaan lateral hidung, keliling kranial, dan papila insisivum. Pedoman ini memiliki beberapa spesifikasi antara lain hubungan antara pengukuran lebar lateral hidung dengan jarak puncak kaninus maksila sesuai dengan penelitian Smith (1957), dan hubungan antara lebar gigi insisivus sentral rahang atas dengan lebarbizigomatik yang diperkirakan 1/16 atau 1/18. Penelitian yang dilakukan oleh Ibrahimagic dkk (2001), terdapat 45\% kecocokan antara bentuk wajah dengan bentuk gigi insisivus sentral rahang atas ras Kaukasoid yakni mendominasi pada bentuk wajah oval dengan bentuk gigi tapered-square. Dalam penelitian terdahulu sudah didapatkan hubungan akan bentuk wajah terhadap bentuk gigi. ${ }^{10,11}$

\section{SIMPULAN}

Golden proportion pada suku Bali yang termasuk ras Mongoloid yakni lebar dan panjang wajah didapat sebesar1 : 1,639 serta pada mesiodistal dan servikoinsisal gigi insisivus sentral rahang atas yaitu sebesar $1: 1,6409$.

\section{DAFTAR PUSTAKA}

1. Geld PV, Oostorveld P, Heck GV, dan Jagtman AMK. Smile attractiveness (selfperception and influence on personality). Angle Orthod 2007; 77(5):759-65.

2. Hamilah DK. Tumbuh Kembang Kraniodentofasial, FKG Trisakti; 2004. h. 1348.

3. Da Silva GC, Castilhos ED, Masotti AS, and Rodrigues-Junior SA. Dental esthetic selfperception of Brazilian dental students. RSBO. 2012; 9(4):375-81

4. Susan N, dan Elham SJ. Tooth Size Discrepancies and Arch Parameters among Different Malocclusions in a Jordanian Sample. The EH Angle Education and Research Foundation Inc.; 2006

5. Hassan MIA, Mohammad HA, Hussain SF. Dental Arch Dimension of Malay Ethnic Group. American Journal of Applied Sciences. 2011.

6. Punagi AQ dan Julianita. Analisis Fotometrik Wajah Suku-Suku di Sulawesi Selatan dan Sulawesi Barat. Majalah Kedokteran Indonesia. 1999; 58(10):370-6

7. Putra, Agung E.C.K, Wirasiti dan Irani S, Variasi Bentuk Wajah Laki-laki dan Perempuan dari Desa Penglipuran Kabupaten Bangli Provinsi Bali, Jurnal Biologi Udayana 2017, 21(2):56-63 
8. Rizki MR dan Nawangwulan S. Metodologi Penelitian Kesehatan. Sidoarjo: Indonesia Pustaka; 2018

9. Rakosi T, Jonas I, Graber TM, Orthodontic Diagnosis, Thieme Medical Publishers Inc, New York; 1993: 109.

10. Jefferson Y, Facial Beuaty-establishing a Universal Standard, IJO 2004;15(1):9

11. Ifwandi, Rahmayani L, Maylanda A. Proporsi Tinggi Wajah pada Relasi Molar Klas I dan Klas II Divisi 2 Angle Mahasiswa Fakultas Kedokteran Gigi Universitas Syiah Kuala. J Syiah Kuala Dent Soc. 2016; 1(2):153-160.
12. Smith F. Measurement of Sheet Resistivities with the Four Point Probe, The Bell System Technical Journal. 1957

13. Ibrahimagic L, Jerolimov VA, Celebic V, Baucic CI and Zlataric DK. Relationship between the Face and the Tooth Form. Coll. Antropol. 2001; (2): 619-626. 